\title{
STRES IBU DALAM MENGASUH ANAK PADA KELUARGA DENGAN ANAK PERTAMA BERUSIA DI BAWAH DUA TAHUN
}

\author{
Dian Yunita Sari ${ }^{* *}$, Diah Krisnatuti ${ }^{2}$, Lilik Noor Yuliati ${ }^{2}$ \\ ${ }^{1}$ Program Studi IImu Keluarga dan Perkembangan Anak, Sekolah Pascasarjana, Institut Pertanian Bogor, \\ Bogor 16680, Indonesia \\ ${ }^{2}$ Departemen IImu Keluarga dan Konsumen, Fakultas Ekologi Manusia, Institut Pertanian Bogor, \\ Bogor 16680, Indonesia \\ *)E-mail:die.yunta@gmail.com
}

\begin{abstract}
Abstrak
Praktik pengasuhan seringkali menjadi sumber stress tersendiri bagi orang tua khususnya yang masih memiliki anak usia dini. Penelitian ini bertujuan untuk menganalisis pengaruh karakteristik keluarga, sumber stres, alokasi waktu mengasuh, pengeluaran keluarga untuk anak, dukungan sosial, dan ketersediaan dukungan peralatan rumah tangga terhadap stres ibu dalam mengasuh anak pada keluarga dengan anak pertama berusia di bawah dua tahun. Pengum pulan data dilakukan dengan wawancara pada 60 orang ibu bekerja dan 60 or ang ibu tidak bekerja di Kota Depok, Provinsi Jawa Barat. Data yang telah dikumpulkan dianalisis menggunakan uji korelasi dan uji regresi linear berganda. Uji korelasi menemukan bahwa stres ibu dalam mengasuh anak berhubungan signifikan negatif dengan pendidikan ayah, pendidikan ibu, pengeluaran keluarga untuk anak, dan ketersediaan dukungan peralatan rumah tangga, serta berhubungan signifikan positif dengan sumber stres. Berdasarkan uji regresi linear berganda, stres ibu dipengaruhi oleh pendidikan ayah, s umber stres anak, dan pengeluaran keluarga untuk anak. Sumber stress dari kehadiran anak yang meningkat akan menyebabkan meningkatnya stress ibu. Sebaliknya, pendidikan ayah yang semakin tinggi dan bertambahnya pengeluaran keluarga untuk anak akan menyebabkan berkurangnya stress ibu pada keluarga dengan anak pertama berusia di bawah dua tahun.
\end{abstract}

Kata kunci: alokasi waktu, dukungan sosial, pengeluaran untuk anak, peralatan rumah tangga, sumber stres

\section{Mother's Parenting Stress in Family with First Children under Two Years Old}

\begin{abstract}
Parenting practice is often become a source of stress for parents, especially for family who still has young children. The aim of this research was to analyze the influence of family characteristic, source of stress, allocation of parenting time, family expenses for children, social support, and home appliances on mother's stress. The design of the research was cross sectional study and involved 120 mothers who had first children under two years old (60 working mothers and 60 nonworking mothers). The sample selected by purposive sampling; the study sites were Ratujaya and Bojong Pondok Terong Village, Depok City, West Java Province. The analysis data use correlation and multiple linear regresion tests. The study revealed that mother's parenting stress had negative significant correlation with father's education, mother's education, and family expenses for children; but had positive significant correlation with source of stress. The multiple linear regression found that mother's stress was influenced by father's education, source of stress, and family expenses for children. Source of stress that was caused by the presence of children influenced significantly increasing of mother's stress. On the contrary, increasing of father's education and increasing of family expenses for children caused significantly decreasing of stress among mothers in family with first children under two years old.
\end{abstract}

Keywords: children expenses, home appliances, mother's stress, social support, sources of stress

\section{PENDAHULUAN}

Peningkatan partisipasi perempuan untuk bekerja di sektor publik sudah menjadi suatu hal yang lazim. Angka partisipasi angkatan kerja pada bulan Februari tahun 2013 adalah 69,21 persen. Angka ini meningkat dibandingkan dengan angka partisipasi angkatan kerja di akhir tahun 2012 yaitu sebesar 67,88 persen (BPS, 2013).

Keikutsertaan perempuan dalam bekerja di sektor publik menyebabkan perempuan memiliki peran ganda. Peran yang harus dijalankan perempuan bekerja adalah peran di sektor domestik (contoh: istri dan ibu), dan juga 
peran di sektor publik (contoh: karyawan). Peran ganda yang diemban dapat menjadi sumber stres. Salah satu dampak dari adanya peran ganda ini adalah kelelahan. Tackett (2007) menyebutkan bahwa gangguan tidur dan kelelahan yang terjadi pada perempuan setelah memiliki anak merupakan sumber stres fisik dan psikologis yang dapat meningkatkan risiko stres pada ibu. Hal lain yang akan dihadapi oleh pasangan yang baru memiliki anak pertama adalah berkurangnya waktu dengan pasangan dan menurunkan peluang untuk kembali bekerja mendapatkan penghasilan (Craig, 2005).

Kehadiran anak pertama merupakan periode kritis bagi orang tua, karena pekerjaan rumah tangga akan semakin bertambah, membutuhkan waktu dan perhatian untuk merawat anak, serta mengurangi waktu istirahat (Duvall, 1971). Anak usia di bawah dua tahun masih banyak memerlukan waktu, kasih sayang, perhatian, dan stimulasi untuk perkembangan mental serta ASI ekslusif yang seharusnya diberikan oleh ibu.

Kehadiran anak berkontribusi terhadap meningkatnya total pengeluaran keluarga. Temuan Kusumo, Sunarti, \& Pranadji (2008); Rosidah, Hartoyo, \& Muflikhati (2012) menyatakan bahwa bertambahnya jumlah anggota keluarga akan menambah beban keluarga. Hal ini terjadi karena kebutuhan keluarga juga bertambah dengan adanya penambahan jumlah anggota keluarga. Duvall (1971) menyatakan bahwa keluarga akan mengalokasikan pengeluaran khusus anak seperti kebutuhan prioritas pembelian susu, perawatan kesehatan, popok, mainan, keamanan, dan perlindungan anak. Apabila keluarga tidak mempersiapkan kebutuhan finansial secara memadai dapat menjadi sumber tekanan yang dirasakan oleh ibu.

\footnotetext{
Memanfaatkan dukungan sosial merupakan upaya meringankan peran pengasuhan serta memberikan dukungan psikologis bagi ibu. Selanjutnya, memanfaatkan home appliances merupakan suatu cara yang dapat digunakan oleh ibu untuk menjaga produktivitas serta meringankan beban pekerjaan rumah tangga. Strober \& Weinberg (1980) menyebutkan beberapa strategi untuk mengatasi keterbatasan sumber daya keluarga yaitu subtitusi tenaga kerja baik yang tidak dibayar maupun dibayar (dukungan sosial) dan strategi subtitusi barang modal (home appliances atau peralatan rumah tangga).
}

Pemaparan tersebut menunjukkan bahwa hadirnya anak pertama selain membawa suatu kebahagian juga menjadi sumber stres pada ibu. Penelitian Tackett (2007) menyebutkan bahwa ketegangan ibu secara signifikan dipengaruhi oleh bayi sehingga ibu mengalami stres. Sunarti \& Syahrini (2011) menyatakan bahwa transisi menjadi orang tua menyebabkan berkurangnya waktu bersama pasangan, rendahnya waktu luang dan berkurangnya keintiman antarpasangan sehingga menyebabkan ketegangan dan stres. Faktor lainnya seperti perubahan ekonomi dalam keluarga juga memiliki peran dalam meningkatkan stres pada ibu.

Penelitian mengenai analisis alokasi pengeluaran untuk anak usia di bawah dua tahun, yang hubungannya dengan tingkat stres ibu saat mengasuh masih belum banyak dilakukan. Oleh karena itu, penting untuk melakukan penelitian ini sebagai upaya mengidentifikasi sumber-sumber stres yang dapat berpengaruh terhadap stres ibu saat mengasuh.

Penelitian ini bertujuan untuk menganalisis sumber stres, alokasi waktu untuk mengasuh, pengeluaran untuk anak, dukungan sosial, home appliances, serta stres ibu saat mengasuh pada keluarga dengan anak pertama berusia di bawah dua tahun, menganalisis hubungan antarvariabel penelitian, dan menganalisis pengaruh karakteristik keluarga, sumber stres, alokasi waktu mengasuh, pengeluaran untuk anak, dukungan sosial, dan home appliances terhadap stres ibu saat mengasuh anak.

\section{METODE}

Penelitian ini menggunakan desain cross sectional. Lokasi penelitian dipilih secara purposive yaitu di Kelurahan Ratujaya dan Kelurahan Bojong Pondok Terong, Kecamatan Cipayung, Kota Depok, Provinsi Jawa Barat. Kecamatan Cipayung dipilih dengan pertimbangan bahwa Kecamatan Cipayung merupakan kecamatan dengan dengan Indeks Pembangunan Manusia (IPM) terendah di Kota Depok, Provinsi Jawa Barat (BAPPEDA \& BPS Kota Depok, 2011). Pengambilan data penelitian dilaksanakan sejak bulan April sampai dengan bulan November tahun 2014.

Penelitian ini melibatkan 120 keluarga dengan anak pertama berusia di bawah dua tahun (baduta). Responden penelitian adalah ibu yang terdiri atas ibu bekerja (60 orang) dan 
ibu tidak bekerja (60 orang) yang dipilih secara nonproportional random sampling.

Data primer yang dikumpulkan dalam penelitian ini terdiri atas karakteristik keluarga, sumber stres, alokasi waktu mengasuh, pengeluaran untuk anak, dukungan sosial, home appliances, dan stres ibu. Data dikumpulkan melalui wawancara pada ibu dengan alat bantu kuesioner. Karakteristik keluarga meliputi usia orang tua, lama pendidikan orang tua, status pekerjaan orang tua, pendapatan keluarga, dan pengeluaran keluarga.

Sumber stres yang diukur adalah sumber stres individu dan anak. Sumber stres individu adalah kesulitan yang muncul pada ibu karena hadirnya anak pertama. Kuesioner untuk mengukur sumber stres individu dimodifikasi dari Family Stressor (McCubbin \& Patterson, 1983), Family System-Strenght Inventory (Mischke \& Hanson, 1996), Family Events Checklist (Fisher, Fagot, \& Leve, 1998). Kuesioner terdiri atas sembilan pertanyaan dengan lima pilihan jawaban yaitu sangat tidak setuju (skor 1) sampai dengan sangat setuju (skor 5). Kuesioner yang digunakan telah reliabel dengan nilai Cronbach's alpha sebesar 0,587 . Sumber stres anak adalah tekanan yang muncul dari berbagai macam perilaku anak pertama. Kuesioner untuk mengukur sumber stres anak dimodifikasi dari Parenting Stress Indeks (Abidin, 1995). Kuesioner terdiri atas 21 pertanyaan dengan lima pilihan jawaban yaitu sangat tidak setuju (skor 1) sampai dengan sangat setuju (skor 5). Kuesioner ini juga telah reliabel dengan nilai Cronbach's alpha sebesar 0,663 .

Alokasi waktu untuk mengasuh adalah jumlah waktu yang digunakan ibu untuk mengasuh anak pertama yang berusia baduta yang dinyatakan dalam jam. Alokasi waktu ibu untuk mengasuh anak diukur dengan metode recall kegiatan ibu pada hari kerja (1×24 jam). Alokasi waktu mengasuh dikelompokkan menjadi <4 jam, 4-8 jam, dan >8 jam. Selanjutnya, pengeluaran keluarga untuk anak adalah pengeluaran yang dikeluarkan oleh keluarga untuk memenuhi kebutuhan anak, seperti makanan, pakaian, popok, peralatan mandi, biaya kesehatan, mainan, dan jasa pengasuh. Pengeluaran keluarga untuk anak dinyatakan dalam persentase yang dihitung dengan membandingkan pengeluaran keluarga untuk anak dengan total pengeluaran keluarga.

Sumber dukungan sosial berasal dari ayah, orang tua/mertua, kerabat dekat, sahabat/tetangga, pembantu, dan pengasuh. Kuesioner untuk mengukur dukungan sosial dikembangkan menggunakan pendekatan teori bentuk-bentuk dukungan sosial (Sarafino, 1994). Kuesioner terdiri atas 30 pertanyaan dengan empat pilihan jawaban yaitu tidak pernah (skor 1) sampai dengan sering sekali (skor 5). Nilai Cronbach's alpha untuk kuesioner dukungan sosial adalah 0,678.

Home appliances adalah peralatan rumah tangga yang berfungsi untuk membantu dan meringankan pekerjaan rumah tangga. Kuesioner terdiri atas delapan pertanyaan dengan lima pilihan jawaban yaitu sangat tidak setuju (skor 1) sampai dengan sangat setuju (skor 5). Nilai Cronbach's alpha untuk kuesioner home appliances adalah 0,518. Stres ibu dalam mengasuh anak diukur menggunakan 15 pertanyaan yang terdiri atas lima pilihan jawaban yaitu dari sangat tidak setuju (skor 1) sampai dengan sangat setuju (skor 5). Kuesioner ini dimodifikasi dari Parenting Stress Index (Abidin, 1995). Kuesioner telah reliabel dengan dengan nilai Cronbach's alpha sebesar 0,596.

Skor yang diperoleh pada sumber stres, dukungan sosial, home appliances, dan stres ibu dijumlahkan dan dihitung indeksnya. Setelah dihitung, indeks dikelompokkan menjadi tiga kategori yaitu rendah $(<33,33)$, sedang $(33,34-66,66)$, dan tinggi $(>66,67)$. Selain penghitungan kategori, data juga dianalisis menggunakan uji korelasi untuk menganalisis hubungan antar variabel penelitian dan uji regresi linear berganda. untuk menganalisis pengaruh karakteristik keluarga, sumber stres, alokasi waktu mengasuh, pengeluaran untuk anak, dukungan sosial, dan home appliances terhadap stres ibu dalam mengasuh anak.

HASIL

\section{Karakteristik Keluarga}

Nilai minimum, maksimum, rata-rata, dan standar deviasi untuk karakteristik keluarga yang terdiri atas usia ayah dan ibu, lama pendidikan ayah dan ibu, pendapatan keluarga, dan pengeluaran keluarga disajikan pada Tabel 1. Status pekerjaan seluruh ayah adalah bekerja yaitu bekerja sebagai pegawai negeri sipil $(5,0 \%)$, karyawan $(54,2 \%)$, wiraswasta $(33,3 \%)$, dan buruh $(7,5 \%)$. Sementara itu, separuh ibu tidak bekerja di sektor publik dan separuhnya lagi bekerja sebagai pegawai negeri sipil $(10,0 \%)$, karyawan $(32,5 \%)$, wiraswasta $(4,2 \%)$, dan buruh $(7,5 \%)$. 
Tabel 1 Nilai minimum, maksimum, rata-rata, dan standar deviasi karakteristik keluarga

\begin{tabular}{lrc}
\hline Karakteristik keluarga & $\begin{array}{c}\text { Minimum- } \\
\text { maksimum }\end{array}$ & $\begin{array}{c}\text { Rata-rata } \pm \\
\text { standar } \\
\text { deviasi }\end{array}$ \\
\hline Usia ibu (tahun) & $17-42$ & $25,6 \pm 4,6$ \\
Usia ayah (tahun) & $19-43$ & $29,1 \pm 4,4$ \\
Pendidikan ibu (tahun) & $6-16$ & $11,5 \pm 2,3$ \\
Pendidikan ayah (tahun) & $6-16$ & $11,6 \pm 2,7$ \\
Pendapatan keluarga & $333-$ & $1.080 \pm 571$ \\
(Rp000,00/kapita/bulan) & 2.666 & \\
Total pengeluaran & $570-$ & $1.770 \pm 906$ \\
keluarga (Rp/bulan) & 5.600 & \\
\hline
\end{tabular}

\section{Sumber Stres Ibu}

Sumber stres ibu dinilai dari sumber stres individu dan sumber stres anak. Hasil penelitian yang disajikan pada Tabel 2 menunjukkan bahwa sumber stres individu secara keseluruhan dan sumber stres individu pada ibu bekerja dan tidak bekerja termasuk dalam kategori tinggi. Hasil ini mengindikasikan bahwa kehadiran anak pertama meniimbulkan kesulitan yang tinggi untuk ibu. Sementara itu, sumber stres anak baik secara keseluruhan maupun berdasarkan status pekerjaan ibu termasuk dalam kategori sedang.

Tabel 2 Sebaran, nilai minimum, maksimum, rata-rata, dan standar deviasi sumber stres ibu dalam mengasuh anak (sumber stres individu dan anak)

\begin{tabular}{|c|c|c|c|}
\hline \multirow[b]{2}{*}{ Kategori } & \multicolumn{2}{|c|}{ Status pekerjaan ibu (\%) } & \multirow[b]{2}{*}{ Total (\%) } \\
\hline & $\begin{array}{c}\text { Ibu } \\
\text { bekerja }\end{array}$ & $\begin{array}{c}\text { Ibu tidak } \\
\text { bekerja }\end{array}$ & \\
\hline \multicolumn{4}{|l|}{$\begin{array}{l}\text { Sumber } \\
\text { stres } \\
\text { individu }\end{array}$} \\
\hline Rendah & 3,4 & 1,7 & 2,5 \\
\hline Sedang & 48,3 & 45,0 & 46,7 \\
\hline Tinggi & 48,3 & 53,3 & 50,8 \\
\hline Total & 100,0 & 100,0 & 100,0 \\
\hline $\begin{array}{l}\text { Minimum- } \\
\text { Maksimum }\end{array}$ & $17-89$ & $25-92$ & $17-92$ \\
\hline $\begin{array}{l}\text { Rata-rata } \\
\text { Standar } \\
\text { deviasi }\end{array}$ & $62,7 \pm 15,8$ & $65,5 \pm 14,5$ & $64,1 \pm 15,2$ \\
\hline \multicolumn{4}{|l|}{$\begin{array}{l}\text { Sumber } \\
\text { stres anak }\end{array}$} \\
\hline Rendah & 11,7 & 16,7 & 14,1 \\
\hline Sedang & 83,3 & 80,0 & 81,7 \\
\hline Tinggi & 5,0 & 3,3 & 4,2 \\
\hline Total & 100,0 & 100,0 & 100,0 \\
\hline $\begin{array}{l}\text { Minimum- } \\
\text { Maksimum }\end{array}$ & $21-73$ & $18-76$ & $18-76$ \\
\hline 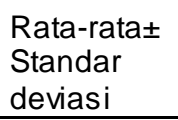 & $44,9 \pm 11,2$ & $46,0 \pm 12,7$ & $45,4 \pm 11,9$ \\
\hline
\end{tabular}

\section{Pengeluaran untuk Anak}

Rata-rata keluarga mengalokasikan 42,4 persen pengeluarannya untuk memenuhi kebutuhan anak, seperti makanan (susu formula dan makanan penunjang ASI), pakaian, diapers atau popok, peralatan mandi, biaya kesehatan, mainan, dan jasa pengasuh. Berdasarkan status pekerjaan, keluarga dengan ibu bekerja mengalokasikan 50,5 persen pengeluarannya untuk anak, sedangkan keluarga dengan ibu tidak bekerja mengalokasikan pengeluarannya sebesar 34,4 persen. Hasil ini mengindikasikan bahwa pengeluaran keluarga yang dialokasikan untuk memenuhi kebutuhan anak pada ibu bekerja lebih tinggi dibandingkan dengan ibu tidak bekerja.

\section{Alokasi Waktu Mengasuh}

Waktu mengasuh anak dinilai dari waktu yang dialokasikan oleh ibu untuk anak, seperti memandikan, mengenakan pakaian, menyiapkan makanan dan minuman, menyusui, menyuapi, menemani bermain, menggendong, dan menidurkan anak. Hasil penelitian yang disajikan pada Tabel 3 menunjukkan bahwa sebagian besar ibu mengalokasikan waktu selama 4-8 jam per hari untuk anak dengan rata-rata sebesar 5,3 jam/hari.

Berdasarkan status pekerjaan ibu, sebagian besar ibu yang bekerja dan tidak bekerja juga mengalokasikan waktu selama 4-8 jam per hari untuk anaknya. Akan tetapi, ratarata waktu yang dialokasikan oleh ibu bekerja $(4,0 \mathrm{jam} / \mathrm{hari})$ lebih rendah dibandingkan dengan rata-rata waktu yang dialokasikan oleh ibu tidak bekerja (7,3 jam/hari). Sebaran, nilai minimum, maksimum, rata-rata, dan standar deviasi alokasi waktu ibu untuk mengasuh anak disajikan pada Tabel 3.

Tabel 3 Sebaran, nilai minimum, maksimum, rata-rata, dan standar deviasi alokasi waktu ibu untuk mengasuh anak

\begin{tabular}{lccr}
\hline \multirow{2}{*}{ Kategori } & \multicolumn{2}{c}{ Status pekerjaan ibu } & \\
\cline { 2 - 3 } & $\begin{array}{c}\text { Ibu } \\
\text { bekerja } \\
(\%)\end{array}$ & $\begin{array}{c}\text { lbu tidak } \\
\text { bekerja } \\
(\%)\end{array}$ & Total $(\%)$ \\
\hline$<4$ jam & 20,0 & 21,7 & 20,8 \\
$4-8$ jam & 76,7 & 68,3 & 72,5 \\
$>8$ jam & 3,3 & 10,0 & 6,7 \\
\hline Total & 100,0 & 100,0 & 100,0 \\
Minimum- & $1,3-8,0$ & $4,0-11,0$ & $1,3-11,0$ \\
Maksimum & & & $5,3 \pm 2,3$ \\
Rata-rata & $4,0 \pm 1,7$ & $7,3 \pm 1,6$ & \\
Standar & & & \\
deviasi & & & \\
\hline
\end{tabular}




\section{Dukungan Sosial}

Dukungan sosial yang diterima ibu berasal dari ayah, orang tua atau mertua, kerabat dekat, sahabat atau tetangga dekat, pembantu, dan juga pengasuh. Hasil penelitian menunjukkan bahwa sebagian besar ibu (60\%) mendapatkan dukungan sosial yang termasuk dalam kategori sedang. Apabila dilihat berdasarkan status pekerjaan ibu maka dukungan sosial yang diperoleh ibu bekerja (81,7\%) termasuk dalam kategori rendah, sedangkan dukungan sosial yang diperoleh ibu tidak bekerja $(61,7 \%)$ berada pada kategori sedang. Nilai minimum, nilai maksimum, nilai rata-rata, dan standar deviasi dari dukungan sosial yang diperoleh ibu bekerja dan tidak bekerja disajikan pada Tabel 4.

Tabel 4 Sebaran, nilai minimum, maksimum, rata-rata, dan standar deviasi dukungan sosial, home appliance, dan tingkat stres ibu

\begin{tabular}{|c|c|c|c|}
\hline \multirow[b]{2}{*}{ Kategori } & \multicolumn{2}{|c|}{ Status pekerjaan ibu } & \multirow[b]{2}{*}{ Total (\%) } \\
\hline & $\begin{array}{c}\text { Bekerja } \\
(\%)\end{array}$ & $\begin{array}{c}\text { Tidak } \\
\text { bekerja } \\
(\%)\end{array}$ & \\
\hline \multicolumn{4}{|l|}{$\begin{array}{l}\text { Dukungan } \\
\text { sosial }\end{array}$} \\
\hline Rendah & 13,3 & 61,7 & 37,5 \\
\hline Sedang & 81,7 & 38,3 & 60,0 \\
\hline Tinggi & 5,0 & 0,0 & 2,5 \\
\hline Total & 100,0 & 100,0 & 100,0 \\
\hline $\begin{array}{l}\text { Minimum- } \\
\text { Maksimum }\end{array}$ & $20,8-71,7$ & $15,8-50,0$ & $15,8-71,7$ \\
\hline $\begin{array}{l}\text { Rata-rata } \\
\text { Standar } \\
\text { deviasi }\end{array}$ & $42,5 \pm 8,9$ & $32,8 \pm 6,5$ & $37,6 \pm 9,2$ \\
\hline \multicolumn{4}{|l|}{$\begin{array}{l}\text { Home } \\
\text { Appliances }\end{array}$} \\
\hline Rendah & 16,7 & 30,0 & 23,3 \\
\hline Sedang & 63,3 & 56,7 & 60,0 \\
\hline Tinggi & 20,0 & 13,3 & 16,7 \\
\hline Total & 100,0 & 100,0 & 100,0 \\
\hline $\begin{array}{l}\text { Minimum- } \\
\text { Maksimum }\end{array}$ & $0-73$ & $0-78$ & $0-84$ \\
\hline $\begin{array}{l}\text { Rata-rata } \\
\text { standar } \\
\text { deviasi }\end{array}$ & $52,9 \pm 18,5$ & $44,4 \pm 18,8$ & $48,7 \pm 19,1$ \\
\hline \multicolumn{4}{|l|}{$\begin{array}{l}\text { Tingkat } \\
\text { Stres lbu }\end{array}$} \\
\hline Rendah & 1,7 & 1,7 & 1,7 \\
\hline Sedang & 66,7 & 70,0 & 68,3 \\
\hline Tinggi & 31,7 & 28,3 & 30,0 \\
\hline Total & 100,0 & 100,0 & 100,0 \\
\hline $\begin{array}{l}\text { Minimum- } \\
\text { Maksimum }\end{array}$ & $30,0-85,0$ & $30,0-92,0$ & $30,0-92,0$ \\
\hline $\begin{array}{l}\text { Rata-rata } \\
\text { Standar } \\
\text { deviasi }\end{array}$ & $57,0 \pm 12,4$ & $59,9 \pm 12,1$ & $58,4 \pm 12,2$ \\
\hline
\end{tabular}

\section{Home Appliances}

Tabel 4 juga menyajikan nilai minimum, maksimum, rata-rata, dan standar deviasi dari home appliance pada keluarga dengan ibu bekerja dan tidak bekerja Sebagian besar keluarga memiliki 5-8 jenis home appliances. Peralatan yang dimiliki keluarga ini sangat membantu keluarga dalam menyelesaikan pekerjaan rumah. Hasil penelitian menunjukkan bahwa persentase tertinggi manfaat home appliances yang dirasakan ibu, baik pada ibu bekerja maupun tidak bekerja termasuk dalam kategori sedang.

\section{Tingkat Stres Ibu saat Mengasuh}

Tingkat stres ibu baik secara keseluruhan maupun berdasarkan status pekerjaan ibu termasuk kategori sedang. Sebaran, nilai minimum, maksimum, rata-rata, dan standar deviasi tingkat stres ibu disajikan pada Tabel 4 .

Hubungan antara Karakteristik Keluarga, Sumber Stres, Alokasi Waktu Mengasuh, Pengeluaran untuk Anak, Dukungan Sosial, dan Home Appliances dengan Stres lbu

Hasil uji korelasi menunjukkan bahwa pendidikan ayah $(r=-0,317, \quad p<0,01)$ dan pendidikan ibu $(r=-0,187, p<0,05)$ berhubungan signifikan negatif dengan stres ibu. Hasil ini menunjukkan bahwa pendidikan ayah dan ibu yang semakin tinggi berdampak pada menurunnya stres ibu. Selain itu, pengeluaran keluarga untuk anak $(r=-0,259, p<0,01)$ yang semakin besar dan juga manfaat home appliances $(r=-0,188, p<0,05)$ yang semakin rendah juga berdampak pada menurunnya stres ibu. Stres ibu semakin besar dengan bertambahnya sumber stres baik sumber stres individu $(r=0,185, \quad p<0,05)$ maupun sumber stres anak $(r=0,426, p<0,01)$. Usia orang tua, status pekerjaan ibu, pendapatan keluarga, pengeluaran keluarga, alokasi waktu untuk mengasuh, dan dukungan sosial tidak berhubungan signifikan dengan stres ibu (p>0,05).

\section{Pengaruh Karakteristik Keluarga, Sumber Stres, Alokasi Waktu untuk Mengasuh, Pengeluaran Keluarga untuk Anak, Dukungan Sosial, dan Home Appliances terhadap Stres Ibu}

Model yang disusun untuk menganalisis pengaruh karakteristik keluarga, sumber stres, alokasi waktu untuk mengasuh, pengeluaran keluarga untuk anak, dukungan sosial, dan home appliances terhadap stres ibu memiliki 
koefisien determinasi (Adjusted $R$ Square) sebesar 0,217. Nilai ini menunjukkan bahwa model mampu menganalisis 21,7 persen pengaruh variabel bebas terhadap stres ibu, sedangkan 78,3 persen lainnya dijelaskan oleh variabel lain.

Uji regresi linear berganda menemukan bahwa stres ibu dipengaruhi oleh pendidikan ayah $(\beta=-1,173, \quad p<0,05)$, sumber stres anak $(\beta=0,386, \quad p<0,01)$, dan pengeluaran keluarga untuk anak $(\beta=-0,109, \quad p<0,10)$. Pendidikan ayah berpengaruh signifikan negatif terhadap stres ibu. Hasil ini menunjukkan bahwa peningkatan lama ayah dalam mengikuti pendidikan formal sebanyak satu satuan dapat menurunkan stres ibu sebanyak 1,173 satuan. Stres ibu juga dapat menurun sebanyak 0,109 dengan bertambahnya satu satuan alokasi pengeluaran keluarga untuk memenuhi kebutuhan anak. Selain itu, stres pada ibu dapat meningkat sebanyak 0,384 satuan dengan dengan bertambahnya satu satuan sumber stres anak. Hasil analisis variabel yang memengaruhi stress ibu dalam mengasuh anak pertama yang berusia di bawah dua tahun disajikan pada Tabel 7.

Tabel 7 Koefisien regresi untuk menganalisis pengaruh karakteristik keluarga, sumber stres, alokasi waktu mengasuh, pengeluaran keluarga untuk anak, dukungan sosial, dan home appliances terhadap stres ibu saat mengasuh

\begin{tabular}{|c|c|c|}
\hline Variabel & Beta & Sig. \\
\hline $\begin{array}{l}\text { Status pekerjaan ibu ( } 0 \text { =tidak } \\
\text { bekerja, } 1=\text { bekerja) }\end{array}$ & 0,091 & 0,979 \\
\hline Usia ibu (tahun) & 0,008 & 0,971 \\
\hline Pendidikan ayah (tahun) & $-1,173$ & $0,046^{\star *}$ \\
\hline Pendidikan ibu (tahun) & 0,124 & 0,822 \\
\hline $\begin{array}{l}\text { Pendapatan keluarga } \\
\text { (Rp000,00/kapita/bulan) }\end{array}$ & 0,005 & 0,125 \\
\hline $\begin{array}{l}\text { Pengeluaran keluarga } \\
\text { (Rp000,00/bulan) }\end{array}$ & $-0,001$ & 0,579 \\
\hline Sumber stres individu & 0,134 & 0,512 \\
\hline Sumber stres anak & 0,386 & $0,000^{* * *}$ \\
\hline Waktu untuk mengasuh (jam) & 0,678 & 0,338 \\
\hline $\begin{array}{l}\text { Pengeluaran keluarga untuk } \\
\text { anak (\%) }\end{array}$ & $-0,109$ & $0,063^{*}$ \\
\hline Dukungan sosial & $-0,142$ & 0,561 \\
\hline Home appliances & 0,032 & 0,825 \\
\hline $\mathrm{F}$ & & 3,748 \\
\hline Sig. & & $0,000^{* *}$ \\
\hline $\mathrm{R}^{2}$ & & 0,296 \\
\hline Adjusted R Square & & 0,217 \\
\hline $\begin{array}{l}\text { Keterangan: } \\
{ }^{*} \text { Signifikan pada } p<0,1 \\
{ }^{\star *} \text { Signifikan pada } p<0,05 \\
{ }^{* \star} \text { Signifikan pada } p<0,01\end{array}$ & & \\
\hline
\end{tabular}

\section{PEMBAHASAN}

Penelitian terdahulu menyebutkan bahwa tingkat stres yang dimiliki oleh ibu tidak bekerja lebih tinggi dibandingkan dengan ibu yang bekerja (Utami \& Puspitadewi, 2012; Ananda, 2013). Hal ini dapat terjadi karena penghargaan atas diri yang dimiliki ibu bekerja lebih tinggi dan hal ini yang mampu meningkatkan konsep diri ibu sehingga menurunkan stres. Akan tetapi, penelitian ini tidak menemukan pengaruh yang signifikan dari status pekerjaan ibu (bekerja dan tidak bekerja) terhadap stres ibu dalam mengasuh anak pertama yang berusia baduta.

Penelitian ini menemukan bahwa pendidikan orang tua menentukan stres ibu. Dalam penelitian ini, pendidikan yang ber-pengaruh terhadap stres ibu adalah pendidikan ayah. Pertambahan lama ayah dalam menempuh pendidikan formal dapat menurunkan stres ibu dalam mengasuh anak. tingkat stres. Ayah yang berpendidikan tinggi dapat membantu pasangannya dalam menghadapi masalah sehingga ketegangan dan juga stres yang dialami oleh pasangan (ibu) berkurang. Menurut Almeida (2005), individu dengan pendidikan yang rendah memiliki stres yang lebih tinggi sehingga individu tersebut mengalami kesulitan dalam menghadapi masalah. Kumar (2008); Rosidah, Hartoyo, \& Muflikhati (2012); Patil (2014) menemukan bahwa pendidikan orang tua yang tinggi memengaruhi tingginya strategi koping, membuka peluang bagi ayah untuk memiliki pekerjaan yang baik, serta meningkatkan kesejahteraan keluarga yang pada akhirnya dapat mengurangi stres ibu.

Sumber stres yang tinggi juga berkontribusi dalam meningkatkan stres ibu. Sumber stres yang meningkatkan stres ibu dalam penelitian ini adalah sumber stres anak. Sumber stres ibu yang berasal dari anak diantaranya adalah anak susah makan, susah tidur atau tidur larut malam, kurang ceria, perkembangannya lambat, temperamen, serta rewel. Keadaan tersebut meningkatkan stres ibu. Temuan ini sejalan dengan hasil penelitian Nystrom \& Ohrling (2004); Maulana dan Sutatminingsih (2005); Cahyo et al. (2008) yaitu tangisan anak dan perilaku sulit anak (temperamen anak) menyebabkan ketegangan dan menjadi sumber stres pada ibu.

Berdasarkan penelitian sebelumnya, sumber stres individu yang muncul setelah memiliki anak dan juga saat mengasuh anak memiliki andil dalam meningkatkan stres ibu. Hal ini dapat terjadi karena kelahiran anak 
pertama dalam keluarga menambah kebutuhan keluarga dan juga menambah pekerjaan rumah tangga. Selain itu, lahirnya anak juga mendorong berkurangnya waktu istirahat dan juga waktu bersama pasangan. Akan tetapi, pada penelitian ini tidak ditemukan adanya pengaruh yang signifikan dari sumber stres individu terhadap stres ibu saat mengasuh. Oleh karenanya, hasil penelitian ini tidak sejalan dengan temuan Craig (2005), Nystrom dan Ohrling (2004), Raikes \& Thompson (2005), Sunarti dan Syahrini (2011), dan Cohen \& Janicki-Deverts (2012) yang mengemukakan bahwa kehadiran anak berdampak pada berkurangnya alokasi waktu untuk bekerja, masalah keuangan keluarga, jaringan sosial yang menjadi sumber stres ketika memberi kritik atau bahkan menawarkan bantuan. Russeng, Usman, dan Saleh (2007); Putri \& Sudhana (2013); Cahyo et. al, (2008); menambah waktu pekerjaan rumah tangga dan mengasuh anak, tidak bisa tidur, dan berkurangnya waktu dengan pasangan.

Tingginya pengeluaran untuk anak berpengaruh negatif terhadap rendahnya stres ibu saat mengasuh. Hal ini berarti bahwa semakin besar pengeluaran untuk memenuhi kebutuhan anak maka semakin rendah stres ibu. Pengeluaran untuk anak seperti makanan, pakaian, diapers, biaya kesehatan, dan jasa pengasuh merupakan kebutuhan yang harus orang tua penuhi demi perkembangan anak yang baik. Orang tua akan merasa bersalah jika tidak dapat memenuhi kebutuhan dan tanggungjawab tersebut seperti temuan Bianchi (2000) bahwa tujuan utama ibu adalah agar anaknya bahagia dan memberikan stimulasi psikososial yang baik setelah memastikan kebutuhan dasar seperti gizi dan pakaian serta keamanan dan kenyamanan yang memadai.

Home appliances memiliki hubungan negatif terhadap stres ibu, yang berarti bahwa semakin banyak jumlah alat dan semakin tinggi persepsi manfaat home appliances berhubungan dengan semakin rendahnya stres ibu. Keberadaan peralatan ini mampu meringankan beban pekerjaan rumah tangga dan berhubungan dengan penurunan tingkat stres. Nystrom dan Ohrling (2004) menemukan bahwa merawat anak itu berat dan menuntut pekerjaan serta dengan memiliki anak ibu harus berjuang dengan keterbatasan waktu, sehingga dibutuhkan strategi untuk mengatasi masalah tersebut. Salah satu strategi untuk manajemen keterbatasan waktu yaitu dengan subtitusi barang-barang modal (capital goods) (Strober \& Weinberg, 1980). Strategi ini dapat dengan memanfaatkan barang atau teknologi yang fungsinya meringankan pekerjaan rumah tangga yang selanjutnya disebut sebagai home appliances.

\section{SIMPULAN DAN SARAN}

Sumber stres individu pada keluarga dengan ibu bekerja dan tidak bekerja termasuk dalam kategori tinggi, sedangkan sumber stres anak, dukungan sosial, home appliances, dan stres ibu dalam mengasuh termasuk dalam kategori sedang. lbu bekerja dan ibu tidak bekerja mengalokasikan waktu selama 4-8 jam per hari untuk mengasuh anak. Keluarga mengalokasikan sebesar $50,5 \%$ (ibu bekerja) dan $34,4 \%$ (ibu tidak bekerja) pengeluarannya untuk memenuhi kebutuhan anak. Status pekerjaan ibu, usia ibu, pendapatan keluarga, pengeluaran keluarga, sumber stres individu, alokasi waktu untuk mengasuh, dukungan sosial, dan home appliances tidak berpengaruh signifikan terhadap stres ibu.

Stres ibu dipengaruhi oleh pendidikan ayah, sumber stres, dan pengeluaran keluarga untuk anak. Stres ibu meningkat dengan bertambahnya sumber stres anak. Oleh karenanya, ibu disarankan untuk mempelajari tentang pengasuhan anak sebagai upaya dalam menemukan solusi yang tepat untuk menangani masalah pada anak. Selain itu, masalah yang dihadapi ibu harus diselesaikan segera agar masalah tersebut tidak menjadi sumber stres. Stres ibu berkurang dengan meningkatnya pendidikan orang tua yaitu pendidikan ayah. Oleh karenanya, orang tua hendaknya meningkatkan pendidikannya. Stres ibu dalam mengasuh anak juga meningkat dengan bertambahnya pengeluaran keluarga untuk anak sehingga keluarga diharapkan menjadi keluarga sejahtera yang mampu memenuhi kebutuhan anak.

\section{DAFTAR PUSTAKA}

Abidin, R. R. (1995). Parenting stress indexshort form test manual. Charlottesville, US: Pediatric Psychology Press.

Almeida, D. M. (2005). Resilience and vulnerability to daily stressor assessed via diary methods. American Psychological Society. 14(2), 62-68.

Ananda, M. R. (2013). Self esteem antara ibu rumah tangga yang bekerja dengan yang tidak bekerja. Jurnal Online Psikologi, 1(1), 40-54.

[BAPPEDA \& BPS Kota Depok] Badan Pembangunan Daerah dan Badan Pusat Statistik Kota Depok. (2011). Indeks 
pembangunan manusia Kota Depok tahun 2011. Depok, ID: BPS Kota Depok.

Bianchi, S. M. (2000). Maternal employment and time with children: Dramatic change or surprising continuity?. Journal of Demography, 37(4), 401-414.

[BPS Kota Depok] Badan Pusat Statistik. (2013). Tenaga kerja: penduduk 15 tahun ke atas menurut jenis kegiatan, 20042013. Depok, ID: BPS Depok.

Cahyo, K., Rimawati, E., Widagdo, L., \& Solikha, D. A. (2008). Kajian adaptasi sosial psikologis pada ibu setelah melahirkan (post partum) di ruang rawat inap RSUD Kota Semarang. Jurnal Promosi Kesehatan Indonesia, 3(1), 48-54.

Cohen, S., \& Janicki-Deverts, D. (2012). Who's stressed? Dibubution of psychologycal stress in United States in probability samples from 1983, 2006, and 2009. Journal of Applied Social Psychology, 42(6), 1320-1334.

Craig, L. (2005). The money or the care: A comparison of couple and sole parent households' time allocation to work and children. Journal of Social Issues, 40(4), 521-540.

Duvall, E. M. (1971). Family development, fourth edition. Philadelphia, US: J.B. Lippincott Company.

Fischer, P. A., Fagot, B. I., \& Leve, C. S. Assessment of family stress across lowmedium-, and high-risk samples using the family events checklist. Journal of Family Relation, 47, 215-219.

Kumar, G. V. (2008). Psychological stress and coping strategies of the parents of mentally challenged children. Journal of the Indian Academy of Applied Psychology, 34(2), 227-231.

Kusumo, R. A. B., Sunarti, E., \& Pranadji, D. K. (2008). Analisis peran gender serta hubungan dengan kesejahteraan keluarga petani padi dan holtikultura di daerah pinggiran perkotaan. Jurnal Media Gizi dan Masyarakat, 52(2), 52-64.

Maulana, B., \& Sutatminingsih, R. (2005). Stres ditinjau dari harga diri pada ibu yang memiliki anak penyandang retardasi mental. Jurnal Psikologia, 1(1), 9-18.

McCubbin, H. I., \& Patterson J. M. (1983). Social stress and the family: advances and development in family stress theory and research. The Family Stress Process, Marriage \& Family Review, 6(1-2),7-73.
Mischke, K., \& Hanson S. (1996). Family systems stressor-strength inventory (FS31). Hanson S., \& Boyd S (Eds). Family Health Care Nurshing (pp. 394408). Philadelphia, US: F. A. Davi

Nystrom, K., \& Ohrling, K. (2004). Parenthood experience during the childs' first year: Literature review. Journal of Advanced Nursing, 46(3), 319-330.

Patil, S. (2014). Level of stress and coping strategies seen among parents of neonates. Journal of Family Psychology, 3(4), 579-585.

Putri, K. A. K., \& Sudhana, H. (2013). Perbedaan stres pada ibu rumah tangga yang menggunakan dan tidak menggunakan pembantu rumah tangga. Jurnal Psikologi Udayana, 1(1), 94-105.

Raikes, H. A., \& Thompson, R. A. (2005). Efficacy and social support as predictors of parenting stress among families poverty. Infant Mental Health Journal, 26(3), 177-190.

Rosidah, U., Hartoyo, \& Muflikhati, I. (2012). Kajian strategi koping perilaku investasi anak pada keluarga buruh pemetik melati gambir. Jurnal IImu Keluarga \& Konsumen, 5(1), 77-87.

Russeng, S. S., Usman, M., \& Saleh, L. M. (2007). Stres kerja pada perawat di instalasi rawat inap rumah sakit Dr. Tadjuddin Chalid Makassar. Jurnal Media Kesehatan Masyarakat Indonesia, 3(1), 20-24.

Strober, M. H., \& Weinberg, C. B. (1980). Strategies used by working and nonworking wives to reduce time pressures. Journal of Consumer Research, 6(4), 338-348.

Sunarti, E., \& Syahrini, J. S. (2011). Pengelolaan stres pada keluarga korban bencana longsor di Kabupaten Bogor. Jurnal IImu Keluarga \& Konsumen, 4(2), 111-120.

Tackett, K. K. (2007). A new paradigm for depression in new mothers: The central role of inflammation and how breastfeeding and anti-inflamatory treatments protect maternal mental health. International Breastfeeding Journal, 2(6), 1-14.

Utami, P. L., \& Puspitadewi, N. W. S. (2012). Perbedaan tingkat stres ditinjau dari empty nest syndrome dan status ibu. Jurnal Psikologi, 1(1), 1-7. 